University of Michigan Law School

University of Michigan Law School Scholarship Repository

\title{
(How) Should Trade Agreements Deal with Income Tax Issues?
}

\author{
Joel Slemrod \\ University of Michigan \\ Reuven S. Avi-Yonah \\ University of Michigan Law School, aviyonah@umich.edu
}

Available at: https://repository.law.umich.edu/articles/1471

Follow this and additional works at: https://repository.law.umich.edu/articles

Part of the International Trade Law Commons, and the Taxation-Transnational Commons

\section{Recommended Citation}

Avi-Yonah, Reuven S. "(How) Should Trade Agreements Deal with Income Tax Issues?" J. Slemrod, coauthor. Tax L. Rev. 55, no. 4 (2002): 533-54.

This Article is brought to you for free and open access by the Faculty Scholarship at University of Michigan Law School Scholarship Repository. It has been accepted for inclusion in Articles by an authorized administrator of University of Michigan Law School Scholarship Repository. For more information, please contact mlaw.repository@umich.edu. 


\title{
(How) Should Trade Agreements Deal With Income Tax Issues?
}

\author{
JOEL SLEMROD* and REUVEN AVI-YONAH**
}

\section{INTRODUCTION}

What is the relationship between the international tax regime, as embodied in bilateral international tax treaties, and multilateral free trade agreements like the General Agreement on Tariffs and Trade (GATT) ${ }^{1}$ Are their fundamental goals consistent or inconsistent? If they are inconsistent, should the tax treaties or the GATT be changed to remedy the inconsistency? If they are consistent, should the scope of either be expanded to include the other?

These are the underlying policy questions on which this Article is meant to shed light. We begin by stating and, in violation of a longstanding scholarly tradition, briefly answering three intermediate questions. We then expand on the reasoning that leads us to these answers and address the broader questions stated above.

Why are distinctions between trade, investment, and tax agreements becoming increasingly blurred?

The prominence of the trade-in-services negotiations of the Uruguay Round, ${ }^{2}$ and the growing presence of foreign direct investment, has brought to the surface how taxation of factor incomes can constitute a fiscal barrier to free trade. Furthermore, increasing competition for foreign direct investment has led to considerable growth in fiscal incentives that may be distorting.

* Paul W. McCracken Collegiate Professor of Business Economics and Public Policy and Director, Office of Tax Policy Research, University of Michigan.

** Irwin I. Cohn Professor of Law and Director, International Tax LLM Program, University of Michigan.

1 General Agreement on Tariffs and Trade, Oct. 30, 1947, 55 U.N.T.S. 194 [hereinafter GATT].

2 GATT-Multilateral Trade Negotiations: General Agreement on Trade in Services, Dec. 15, 1993, 33 I.L.M. 44. 
Are current trade, investment, and tax policies complementary or potentially conflicting?

Broadly speaking, they are complementary, because free trade requires single taxation of factor incomes, which is a goal of bilateral tax treaties.

\section{What is the current relationship between trade and tax agreements?}

Tax agreements cover investment issues as well as tax issues related to trade in goods and services. Because of their bilateral nature, however, tax treaties cannot effectively address some problems, such as trade- and investment-distorting tax competition. Trade agreements are multilateral but are generally limited to trade-in-goods issues and exclude investment issues and, in some cases, trade in services. Tax and trade agreements share similar nondiscrimination and national treatment provisions, but only trade agreements incorporate most-favored-nation concepts.

\section{Why Trade Agreements Cannot Ignore Taxes}

It is widely accepted that a multilateral agreement covering only tariffs would not be sufficient to achieve free trade. There are a host of nontariff policies that would have a trade-restricting impact, for example, discriminatory government procurement rules and procedures, administrative procedures such as health and sanitary regulations, quantitative restrictions such as quotas, and antidumping rules and procedures. GATT distinguishes between tariffs and other kinds of restrictions, holding that the latter, as a matter of principle, and with exceptions, are to be abolished forthwith; ${ }^{3}$ in contrast, GATT recognizes the reduction of tariffs as a goal to be achieved gradually via agreements among contracting parties. ${ }^{4}$

Of particular interest among nontariff barriers to trade are subsidies, including both production and export subsidies, and taxes, including both indirect and direct taxes.

${ }^{3}$ See, e.g., GATT, note 1 , arts. III (protectionist income taxation and regulation), V (freedom of transit), VI (antidumping), \& XI (quantitative restrictions).

${ }^{4}$ See id. arts. II, I 1(b) (products subject to GATT generally exempted from custom duties "in excess of those set forth" in schedules relating to any contracting party and from "other duties or charges of any kind ... in excess of those imposed on the date of this Agreement"), XXVIII bis, II 1 (recognizing that custom duties "often constitute serious obstacles to trade" and that negotiations to reduce tariffs "on a reciprocal and mutually advantageous basis ... are of great importance to the expansion of international trade"). 


\section{A. Subsidies}

The economic and revenue effects of an import tariff can be replicated exactly by a destination-based consumption tax along with, at equal rate, a subsidy to domestic production. In either case one would expect an increase in the price faced by both domestic consumers and domestic producers. There is, though, no production inefficiencythat is, no fiscal incentive favoring domestic over foreign producerscaused by a consumption tax. Thus, from an economic perspective, the objectionable component of a tariff is its implicit subsidy to domestic producers.

Article XVI of GATT treats subsidies as, in principle, undesirable interferences with the free flow of goods. Section B is concerned exclusively with export subsidies. Section $A$ is more general, applying to any subsidy. It says that if any country maintains a subsidy that increases exports or decreases imports, it must notify the contracting parties of GATT. If serious prejudice to the interests of another contracting party is determined to exist, GATT shall consider the possibility of limiting the subsidy. ${ }^{5}$ Article III: 4 provides that imports be accorded treatment in all laws and regulations "no less favourable" than domestic products, and this presumably applies to production subsidies. Article III:8(b), however, limits the applicability of Article III:4, by providing that it "shall not prevent the payment of subsidies exclusively to domestic producers ...."

Article XVI was significantly expanded by the Subsidies Code included in the 1994 version of GATT. ${ }^{6}$ The Subsidies Code defines "subsidy" as including cases where "government revenue that is otherwise due is foregone or not collected ...." To be actionable under GATT, a subsidy must be "specific to an enterprise or industry or group of enterprises or industries ...." In addition, a specific subsidy is prohibited only if it is "contingent, in law or in fact ... upon export performance" or "upon the use of domestic over imported goods." Annex I to the Subsidies Code includes an "illustrative list of export subsidies," which includes "[t]he full or partial exemption, remission, or deferral specifically related to exports, of direct taxes ... paid or payable by industrial or commercial enterprises."10 A footnote clarifies that this language "is not intended to limit a Member from taking

5 Id. art. XVI, § A, II 1.

6 Agreement on Subsidies and Countervailing Measures, Apr. 15, 1994, Marrakesh Agreement Establishing the World Trade Organization, Annex 1A, Legal InstrumentsResults of the Uruguay Round vol. 1 (1994) [hereinafter Subsidies Code].

7 Id. art. 1, II 1.1(a)(1)(ii).

8 Id. art. 2, II 2.1.

9 Id. art. 3 , I 3.1.

10 Id. annex I, illus. e. 
measures to avoid the double taxation of foreign-source income earned by its enterprises ...."11

The quoted language of the Subsidies Code recognizes that the direct tax system can be the vehicle for providing export subsidies, such as when income ascribed to the production of goods for export is given preferential tax treatment. This type of policy is not fundamentally different from levying a nondiscriminatory income tax as well as providing an export subsidy, in this case at a rate related in a potentially complicated way to the company's income tax situation.

\section{B. Internal Taxes}

Article III of GATT, entitled "National Treatment on Internal Taxation and Regulation," takes up the matter of internal taxes. Paragraph 2 prohibits internal taxes levied on imported products that are in excess of those applied to "like" domestic products. ${ }^{12}$ Paragraph 1 is more general, referring not only to internal taxes but also to other internal laws and regulations, and says that these ". . . should not be applied to imported or domestic products so as to afford protection to domestic production." 13

\section{Direct Taxes}

Because Paragraph 1 of Article III refers to taxes on products, the presumption has always been that direct taxes, in particular income taxes, are not in its purview. In principle, however, a protectionist policy can be effected via the direct tax system. Two categories of such a practice are worth distinguishing. In the first category, the direct tax system just happens to be the vehicle for a protectionist policy. An example is where expenditures for inputs are deductible only if the inputs are domestically-produced goods. This policy is similar to allowing a deduction for all inputs, and levying an import tariff equal to the business tax rate. This particular policy could be applied to intermediate goods, but not to final consumption goods. The individual income tax system, however, could be used to produce a similar effect for final goods: imagine a $10 \%$ individual income tax credit for domestically-produced automobile purchases. In these examples the income tax system serves as the vehicle for offering a discriminatory fiscal advantage to domestically-produced goods. In both examples the protectionist element is completely transparent.

11 Id. n.59.

12 GATT, note 1, art. III(2).

13 Id. art. III(1). 
The second category of direct taxes with a protectionist objective makes use of the fiscal equivalence that (under perfect competition) an output subsidy of a given rate is equivalent to a subsidy at that rate to all inputs. A subsidy to a subset of inputs also acts as a subsidy to output, with the additional impact of causing substitution in the technique of production toward the subsidized input.

Thus, a production subsidy effect can be achieved through direct taxes by applying differentially lower taxes on factors used in a particular sector. A subsidy on cars can be achieved by preferentially taxing labor income derived from the production of cars and/or preferentially taxing capital used in car production. This implies that any multilateral trade agreement that intends to proscribe or limit production subsidies (on which, as the earlier discussion suggests, GATT is ambiguous) must extend its concern to sector-specific subsidies to factor inputs.

In the case of capital taxes, sector specificity can be achieved with what are superficially uniform rules. This can be accomplished by maintaining a uniform tax rate and manipulating other critical aspects such as the tax depreciation schedules, inventory accounting rules, the rate and applicability of investment tax credits, and the system of inflation adjustment. It is widely known that, ignoring any explicitly sector-specific features of tax law, there is wide variation in the effective taxation of capital income across sectors in most, if not all, OECD countries. ${ }^{14}$

There is no evidence that business tax systems in fact have been manipulated to achieve a desired production subsidy equivalent. Nor would it be easy. Setting sector-specific effective production subsidies by altering technical aspects of the tax system would be a tricky business indeed.

In sum, not only sector-specific factor taxes and subsidies, but also statutorily uniform business and labor taxes, if they are source-based, can produce the same kind of locational inefficiencies that trade agreements seek to limit. They are certainly a blunt instrument for a government seeking to protect certain sectors, and therefore may be of limited practical importance, especially in comparison with export subsidies delivered through the tax system.

\section{Services and Foreign Investment}

The underlying objective of GATT is to limit government policies whose aim is to increase domestic production, generally at the ex-

14 OECD, Taxation of Capital in OECD Member Countries (1991); see EU Commission, Company Taxation in the Internal Market (2002). 
pense of imports, and perhaps in only certain sectors. Thus, the location of production is a critical concept. But a concern over where production is located often represents a concern over who receives the benefits of local production. Local workers perceive that their real income is higher if domestic production is higher, as do owners of domestically-located physical capital, land, or location-specific human capital.

There are two areas-services and foreign direct investment-in which the concept of the location of production itself becomes fuzzy, and the distinction between where a product is produced and who produces it becomes blurred. These areas raise particularly challenging policy issues.

\section{Services}

There is no generally accepted comprehensive definition of what constitutes a service. A common classification scheme includes the following sectors as "services": (1) wholesale and retail trade, hotels, and restaurants; (2) transport and communications; (3) finance, insurance, real estate, and business services; and (4) community, social, and personal services. ${ }^{15}$ Robert Stern and Bernard Hoekman identify two distinguishing characteristics of services-nonstorability and intangibility. ${ }^{16}$ Because of these characteristics, in order to be tradable, services have to be applied or embodied in objects, information flows, or persons. Services may or may not require the physical proximity of the producer and consumer.

For the sake of discussion, consider a service for which the provider and consumer must be in physical proximity, and for which the technology dictates that the provider must move to the consumer, rather than vice versa. Free trade would require that, if the most efficient provider of the service was a nonresident, that no fiscal (or regulatory) barriers be erected that would induce the domestic consumer to prefer instead a less efficient domestic provider. Now assume further that the only input to this service is the labor of the provider. In this case an equivalent to an import tariff is a source-based tax on labor provided by foreigners, over and above any labor income tax levied on residents. If this tax is not offset by the residence country, either by means of a foreign tax credit or exemption, then the double taxation of labor income serves as a fiscal barrier to the free trade of this

15 OECD, Science, Technology and Industry Scoreboard 2001-Towards a KnowledgeBased Economy 127 (2001) (table description of various service sectors).

16 Robert M. Stern \& Bernard H. Hoekman, Conceptual Issues Relating to Services in the International Economy, in 1 Trade and Investment in Services in the Asia-Pacific Region 7, 8 (Chung H. Lee \& Seiji Naya eds., 1988). 
service. The mechanism for avoiding double taxation (that is, source or residence country renunciation) is not critical to achieve global efficiency although it will matter for the cross-country allocation of revenue, and therefore welfare.

\section{Foreign Direct Investment ${ }^{17}$}

In the previous example, the source of comparative advantage was expertise embodied in the service provider. The service transaction need not require any physical investment or permanent establishment, just the temporary presence of the service provider.

Next, consider the case where a corporation rather than an individual possesses the expertise, which pertains to a production technique for a tangible good. In order to take global advantage of its expertise, the corporation has three options. It can export the good, it can license the technology to foreign producers, or it can set up a foreign subsidiary to produce the good. If transportation costs are high, the exporting option will not be attractive. If the firm fears that a licensing agreement will not be able to protect its proprietary expertise, that option will not be attractive, leaving foreign direct investment as its best choice.

Analogous to the cross-border service provider, the taxation of the income flows from the foreign direct investment can create a fiscal barrier to free trade. The issue is much more complex, however, because the flows of income from the subsidiary to the foreign parent may represent not only a payment for the use of the expertise, but also a return to a capital investment. ${ }^{18}$ Double taxation of the income from the intangible asset is a fiscal barrier to the efficient application of this corporation's expertise. As above, the institutional mechanism for avoiding double taxation is not critical for global efficiency, but does matter for the inter-nation division of tax revenues.

Of course, the economic ramifications of barriers against inward foreign direct investment are different from the ramifications against barriers to inputs. In either case, domestic consumers will be hurt by the restriction of access to low-cost providers. But, while import re-

17 There are issues on the interface between trade and investment that do not directly involve taxation; we do not discuss them in this Article. A prime example of this kind of issue is the use of TRIMS, or trade-related investment measures, which span a wide range of practices including domestic content requirements, export performance requirements and restrictions, trade balancing rules, mandates on local sale and manufacture, foreign exchange balancing requirements and restrictions, rules governing technology transfer, limitations on remittances, and local equity participation requirements.

18 In the case of a licensing agreement, in which the licensee owns all of the capital, the payment is clearly only for the services of the intangible asset-the expertise-and not for the use of capital per se. 
strictions may help domestic workers, restrictions against foreign direct investment generally will not because they will lose their opportunity to work for the investing multinationals. In either case, when delivery of a good or service is tied to the temporary or permanent movement of factors, source-based taxation of factor incomes can constitute a fiscal barrier to free trade, especially if there is no mechanism for the alleviation of double taxation due to overlapping jurisdictions.

Double taxation is to a large extent alleviated by agreements in bilateral tax treaties that limit double taxation and assign the taxing jurisdiction of various income types between the source and residence countries, and by the unilateral granting of double tax relief by many capital exporting countries, either via limited credits for foreign taxes paid, or by a territorial system of taxation. It is as if all the exporting nations imposed exactly offsetting export subsidies when faced with tariffs imposed by all nations importing a certain good. This would eliminate any attendant trade distortions, and thus would be optimal from a global perspective. Such a system would not be in the exporting countries' interest, however, because it essentially would be a transfer payment to the importing countries' governments. Thus, it is inevitable that the division of revenues becomes an important and contentious element of the current international tax regime. Bilateral tax treaties generally favor a reciprocity clause, ${ }^{19}$ requiring equal withholding levies for capital flows in both directions; this is designed to maintain an "equitable" distribution of revenues in the presence of two-way capital flows. Whether it in fact achieves this goal depends also on the corporate tax rates and the detail of integration systems in place. ${ }^{20}$ In the case where the capital flows are mostly one way, the distribution of revenues may be skewed, which may explain the relative paucity of tax treaties between developed and developing countries.

\section{Border Protectionism Versus Ownership Protectionism}

One important difference between trade policy and tax policy is that while trade policy operates at the border and is blind to corporate residency, tax policy can operate at the margin of corporate residency. For example, tariffs are imposed on all imported products, regardless of whether the good is produced abroad by a foreign-owned company or an affiliate of a domestically-owned company. Domestically-pro-

19 See, e.g., Income Tax Convention, Aug. 16, 1984, U.S.-Can., art. XVII, 1 Tax Treaties (CCH) I 1901.17.

20 See Hugh J. Ault, Corporate Integration, Tax Treaties and the Division of the International Tax Base: Principles and Practices, 47 Tax L. Rev. 565, 576-82 (1992). 
duced goods are not subject to tariffs, and benefit (or suffer, if the imported goods are inputs) from the higher domestic prices caused by tariffs, regardless of whether the producer is domestically-owned or foreign-owned. Thus, trade policy raises the issue of what might be called "border protectionism."

Income taxation, because it can impose differential taxation depending on corporate residence, also may involve another kind of protectionism that we refer to as "ownership protectionism." Whether it does or not depends on the structure of the income tax in place. If, for example, all countries scrupulously practiced nondiscrimination of business enterprises, levied no withholding taxes, and operated territorial systems of taxation, any two corporations with the same real operations and results spread over the world would pay the same total tax, regardless of the residency of the parent corporations and even in the face of varying tax rates across countries. For example, a French company and U.S. company would pay the same total tax if both companies operated exclusively in the United States, exclusively in France, exclusively in Singapore, or in some combination of these and other countries.

In practice, the United States taxes its resident multinationals on a worldwide basis ${ }^{21}$ and France taxes on a territorial basis. ${ }^{22}$ In this case a tax penalty potentially is placed on a U.S. multinational company versus a French multinational company, one that depends on the locational pattern of activity. There would be no substantial difference if the two multinationals operated exclusively in countries of similar tax rates such as France and the United States. The difference arises only to the extent of operations in a low-tax country. The U.S. parent company, but not the French parent, could be subject to a residual tax, but generally only upon repatriation of income from its affiliate in the low-tax country. ${ }^{23}$ The apparent difference also is mitigated if the U.S. multinational operates not only in low-tax countries, but also in foreign countries with average tax rates that exceed the U.S. average rate. In this case the U.S. system allows repatriated income from a low-tax country, such as Ireland, to be "mixed" with repatriated income from a high-tax country, such as Germany, with the result that no net tax need be paid to the U.S. government. ${ }^{24}$

From the standpoint of global efficiency, there is no reason that the total (corporate plus individual) tax burden on the income of a multinational enterprise should depend on the parent company's country

\footnotetext{
21 IRC §§ 11, 61.

22 Francis Lefebvre, France: Legal and Tax Guide § 1103 (1992).

23 IRC $\$ \$ 902$, 904(a).

24 IRC § 904(a), (d).
} 
of incorporation, unless the tax differential reflects variations in the benefits offered by the resident country. ${ }^{25}$ Absent that, this system is no more efficient than in a domestic context taxing corporations with names beginning with the letters $A$ through $K$ at one rate, while taxing at a higher rate those with names beginning with $L$ through $Z$ (and not allowing name changes). If enacted, Lollapollooza Corporation could not compete with Kennebunkport Corporation if they produced exactly the same products. If they produced slightly different products, Lollapollooza might survive, but at a diminished scale and diminished variety of output. As Daniel Frisch has argued, one efficiency cost of this discrimination could be a reduced variety of products available to the world market. ${ }^{26}$

Whether higher corporate taxes translate into higher total taxes depends on the tax system in place. This would not occur if all countries adopted a pure residence-based tax, where residence refers to the residence of individuals and not corporations. Corporations subject to more tax necessarily would have shareholders who had a lower personal tax burden, and so their cost of capital would be low enough to offset the higher corporation tax payments. Under the current international system of taxation, which is not a pure residence-based system and not perfectly integrated, this offset does not occur.

\section{Income Shifting and Tax Havens}

Another important difference between tariff policy and tax policy is that the basis for duties is the value of transaction, while for income tax policy the basis is a measure of income. Income is a considerably more slippery concept to define, and the location of the income of an integrated global enterprise is a conceptual nightmare. Hugh Ault and David Bradford have gone so far as to argue that it is not meaningful. ${ }^{27}$

Given differences in tax rates across countries, and the fact that no country has a pure residence-based system of taxing corporations, there are incentives to take advantage of the difficulty of ascertaining the location of income to reduce an enterprise's worldwide tax burden. A multinational operating in two countries in which the marginal tax rate on a dollar of income is different, ceteris paribus, would pre-

25 One of the authors believes that currently such benefits may still justify making the distinction, although it may disappear in the future. Reuven Avi-Yonah, For Haven's Sake: Reflecting on Inversion Transactions, 95 Tax Notes 1793 (June 17, 2002).

26 Daniel J. Frisch, The Economics of International Tax Policy: Some Old and New Approaches, 47 Tax Notes 581, 590 (Apr. 30, 1990).

27 Hugh J. Ault \& David F. Bradford, Taxing International Income: An Analysis of the U.S. System and its Economic Premises, in Taxation in the Global Economy 11, 32-33 (Assaf Razin \& Joel Slemrod eds., 1990). 
fer to shift the taxing jurisdiction of income from the high-tax country to the low-tax country. Such a shift can be accomplished by the judicious setting of prices of transactions between corporate affiliates, or by judicious international financial policy (for example, borrowing in high-tax countries).

Holding the location of real activity constant, a country gains when a dollar of taxable income is shifted into it, while the country from which it is shifted loses. The world currently is populated by a set of countries, known loosely as tax havens, that set low tax rates and look the other way, or even encourage, the inward shifting of taxable income. To stanch the outward flow of taxable income, countries with relatively high tax rates must establish an enforcement structure to monitor transfer pricing, earnings stripping, and other methods of income shifting.

Tax havens can be classified into two types. In one type, the country levies a very low tax rate on the income from manufacturing operations located in its jurisdiction ("production tax havens"). ${ }^{28}$ In the second type, the country offers a low tax on the income of corporations who establish their legal domicile in that country ("traditional tax havens"). One motivation for becoming the first type of tax haven is to attract real investment and economic activity into the country. This is not a primary motivation for traditional tax havens where the country essentially offers its services, for a fee, to individuals and corporations pursuing tax avoidance and evasion. In the first type, but not in the second, there is usually a domestic tax base that is segregated from the operations benefiting from the low-tax regime in order to limit the revenue loss from the low-tax rate.

Even a production tax haven opportunistically gains from income shifting. Consider Country A, which has a low statutory rate on corporate income reported due to manufacturing operations in that country. Having established an affiliate in Country $A$, a multinational enterprise has an incentive to shift taxable profits to that country from higher-tax countries. Thus, it is no coincidence that such low-tax countries implement a low marginal effective tax rate (METR) on investment via a low statutory tax rate strategy, as opposed to a strategy of a high statutory rate combined with generous investment tax credits and depreciation allowances. Although any particular low METR can be obtained with the latter strategy, it would not make the country a magnet for income shifting, only for real activity.

${ }^{28}$ There are numerous examples of this, including, for example, the recently abolished Irish preferential regime for manufacturing operations and the tax holidays received by Intel in countries such as Israel and Costa Rica. For more detail, see Robert Goulder, Primarolo Group's Report Identifies 66 Harmful Tax Regimes, 20 Tax Notes Int'l. 1283 (Mar. 20, 2000). 
Local content rules are a useful analogy to tax havens in the domain of international trade. Imagine that the United States imposes quantity restrictions on the import of steel from Japan and Korea. In order to enforce such restrictions, there must be a way to identify imports from an unrestricted country, such as Mexico, as having originated in Mexico rather than in Japan or Korea. This usually is accomplished by attempting to measure the "local content" of the imports from Mexico, and requiring it to be above a prespecified level in order to be imported without restriction. These rules are similar to the anti-treaty shopping provisions of income tax treaties, which seek to limit the rerouting of income through tax havens to minimize tax payments. A country which, for some compensation, collaborates with the restricted countries to evade the U.S. local content rules acts similarly to a tax haven. In what follows, we refer to the behavior of tax havens with a concocted term- "predatory tax protectionism." It is predatory because it is clearly a zero sum or, as we argue below, a negative sum game, in which the tax haven's gains are offset by losses to the rest of the world.

From a global perspective, the presence of tax havens is costly for at least two reasons. First, there are substantial resource costs expended by the tax collection agencies of the rest of the world to minimize inappropriate income shifting, and substantial resource costs expended by the multinationals themselves to accomplish such shifting. Second, there are distortions in the kind of real activity that the (first type of) tax haven attracts, that is, high-margin production such as pharmaceuticals and electronics that facilitate income shifting. There is no economic reason why such activities should be located in Ireland or Puerto Rico, absent the income shifting advantages they offer to U.S. corporations.

\section{Bilateral Tax Treaties and Their Limitations}

\section{A. Brief History}

From their modern origin, states have levied direct taxes (taxes imposed on income or property) on one, or both, of two bases: (1) because the person owning the property or receiving income was a resident, or (2) because the income or property was located in the state's territory. That the two bases for taxation raised the possibility of double taxation of foreign source income or foreign-located property was recognized early on.

In the 1920's the League of Nations commissioned several studies of international double taxation and how to alleviate it. These eventually led in 1928 to the issuance of several draft model treaties, which 
provided the framework for the negotiation of a network of treaties, primarily among European countries. ${ }^{29}$

The goal of tax treaties was considered in the initial report, issued in 1923 by four eminent economists. ${ }^{30}$ They argued that, because double taxation represented an unfair burden on exiting investment, and an arbitrary barrier to the free flow of capital, goods, and persons, it was in nations' interests to eliminate or at least limit it. ${ }^{31}$ Of the four methods for alleviating double taxation they considered, exemption by the source state of residents' income was favored. The authors argued that this approach avoided theoretical complexities and accorded with what they viewed as economic reality-that the source country should cede the right to tax when it sought investment from abroad. ${ }^{32}$ They also proposed to divide revenues among countries according to a formula based upon the relative magnitude of the different types of income deemed to have originated in each state. ${ }^{33}$

The League model treaties settled on a different approach, denoted "classification and assignment." ${ }^{4}$ Under this method, income is classified by type and the primary right to tax some types of income are assigned to the source state and other types are assigned to the state of residence. ${ }^{35}$ This is the structure used in nearly all tax treaties. The actual classifications and assignments used today also stem from the League's work in the 1920's. Real property business income connected to a fixed location generally is assigned to the source state. ${ }^{36}$ "Passive" investment income generally is assigned to the residence state. $^{37}$

After World War II, the work of the League of Nations on tax treaties was taken up by the Organisation for European Economic Cooperation (later Organisation for Economic Co-Operation and

${ }^{29}$ Draft Conventions No. I-a, I-b, \& I-c, Report Presented by the General Meeting of Government Experts on Double Taxation and Tax Evasion, League of Nations, Doc. C.562.M.178.1928II (Oct. 31, 1928), reprinted in 4 Staff of Joint Comm. on Tax'n, Legislative History of United States Tax Conventions 4165 (1962) [hereinafter Legislative History].

${ }^{30}$ Report on Double Taxation Submitted to the Finance Committee by Professors Bruins, Einaudi, Seligman, and Sir Josiah Stamp, League of Nations Doc. E.F.S.73.F.19 (1923), reprinted in Legislative History, note 29, at 4049 (1962) [hereinafter 1923 Report].

31 Id. at 4044.

32 Id. at 4046.

33 Id.

${ }^{34}$ See, e.g., Report Presented by the General Meeting of Government Experts on Double Taxation and Tax Evasion, Comment to Draft Convention No. I-a, 10 League of Nations O.J., Annex 1096, at 209 (1929).

35 League of Nations Draft Convention No. I-a, note 29, art. 1.

36 Id. art. 2.

37 Id. arts. $3,9$. 
Development, or OECD). The OECD issued a model treaty in 197738 (revised in $1992^{39}$ and $2000^{40}$ ), which is the basis for most treaties currently in effect. The United States has issued a model treaty, which follows the OECD model in most, but not all, respects. ${ }^{41}$

Coverage of the bilateral treaty network extends to most developed countries, but it is sporadic for developing countries. According to Gary Hufbauer, the income tax treaty networks of the United States, Japan, Germany, and the United Kingdom each cover between $92 \%$ and $98 \%$ of the developed world, measured in terms of GDP or imports. ${ }^{42}$ Hufbauer's calculations indicate, however, that the U.S. income tax treaty network covers only about $22 \%$ of developing country GDP, and $21 \%$ of developing country imports, although the U.S. treaty network with developing countries has expanded significantly since 1991.43 The treaty networks of Japan, Germany, and the United Kingdom each cover between $37 \%$ and $46 \%$ of the developing world, measured by GDP or imports, respectively. ${ }^{44}$

\section{B. Nondiscrimination}

Both the OECD and U.S. model treaties contain articles dealing with nondiscrimination. They state that nationals of a foreign country should not be subjected to any taxation or any connected requirement that is more burdensome than what applies to domestic nationals. ${ }^{45}$ The treaties explicitly extend this provision to permanent establishments of foreign firms, and to enterprises that are wholly or partly owned or controlled by one or more foreign residents. ${ }^{46}$

With certain exceptions, payments of interest, royalties and other disbursements to foreign residents, for the purposes of determining taxable income, are to be deductible under the same conditions as payments to domestic residents. ${ }^{47}$ The first exception applies to con-

38 OECD, Model for the Avoidance of Double Taxation With Respect to Taxes on Income and Capital, Apr. 11, 1977, 1 Tax Treaties (CCH) II 201.

39 OECD, Tax Convention on Income and Capital, July 23, 1992, 1 Tax Treaties (CCH) II 191.

40 OECD Model Tax Convention on Income and on Capital, Apr. 29, 2000, art. 24(1) [hereinafter OECD Model Treaty].

41 U.S. Model Income Tax Convention, Sept. 20, 1996, 1 Tax Treaties (CCH) II 214 [hereinafter U.S. Model Treaty].

42 Gary Hufbauer, Tax Treaties and American Interests: Report to the National Foreign

Trade Council, Inc., app. D, at 4 (Aug. 1988).

43 Id.

44 Id.

45 OECD Model Treaty, note 40, art. 24(1); U.S. Model Treaty, note 41, art. 24(1).

46 OECD Model Treaty, note 40, art. 24(3), (4); U.S. Model Treaty, note 41, art. 24(2), (4).

47 OECD Model Treaty, note 40, art. 24(4); U.S. Model Treaty, note 41, art. 24(3). 
trolled foreign corporations, and allows countries to disregard transactions among the controlled group that differ from those that would be made between independent enterprises. ${ }^{48}$ In order to avoid double taxation, the foreign country is charged with making an appropriate adjustment; competent authorities of the countries involved, if necessary, are to consult with each other to determine the appropriate adjustments. 49

The second exception applies to interest and royalty payments which, because of a special relationship between the payer and the beneficial owner, exceed the amount paid in an arm's-length relationship. ${ }^{50}$ In this case the amount may be adjusted for tax purposes.

\section{Reciprocal Reductions in Withholding Taxes at Source}

Most countries reserve the right to impose "withholding" taxes on remittances paid out of the country in the form of interest, dividends, royalties, fees for investment services, and capital gains. Generally, tax treaties provide for reciprocal reductions from the statutory rates of withholding tax. ${ }^{51}$ The OECD Model Treaty limits the sourcecountry tax on dividends to $5 \%$ for owners of $25 \%$ or more of the company, and $15 \%$ otherwise, ${ }^{52}$ and on interest to $10 \% .{ }^{53}$

\section{The Limits of the Bilateral Treaty Network}

Should a free trader be concerned about the current state of the international tax system? In one important sense, the answer is clearly no. The commitment embodied in bilateral tax treaties and unilateral provisions of capital-exporting countries to avoid double (and zero) taxation is at least broadly consistent with a free trade tax system. One could argue that international tax institutions already have achieved what multilateral trade agreements have been struggling for years to accomplish.

Though the international tax system is broadly consistent with free trade, in its details it clearly falls short. A pure free trade tax system would require a residence-based tax system in all countries, so that the effective tax on labor or capital income for any person did not depend

48 OECD Model Treaty, note 40, art. 9(1); U.S. Model Treaty, note 41, art. 9(1).

49 OECD Model Treaty, note 40, art. 9(2); U.S. Model Treaty, note 41, art. 9(2).

50 OECD Model Treaty, note 40, art. 11(6); U.S. Model Treaty, note 41, art. 11(4) (interest provisions); OECD Model Treaty, note 40, art. 12(4); U.S. Model Treaty, note 41, art. 12(4) (royalty provisions).

51 E.g., Income Tax Convention, Mar. 8, 1971, U.S.-Japan, art. 13(4), 2 Tax Treaties (CCH) II 5203.17.

52 OECD Model Treaty, note 40, art. 10(2).

53 Id. art. 11(2). 
on where the factors were applied to the productive process. This is not the state of affairs due to the prevalence of source-based taxes and the unwillingness or inability of residence countries to perfectly offset these taxes. Note that nondiscrimination or national treatment is not sufficient to prevent this kind of trade distortion. For example, a source-based subsidy to labor income, granted in a nondiscriminatory fashion to domestically-owned and foreign-owned companies, may provide a production subsidy to relatively labor-intensive sectors, in the same way that a tariff on those sectors would.

There are, furthermore, aspects of taxation that on the face of things appear to be discriminatory, because they differentiate tax liability depending on residence. To some extent, these tax features exist because of two important differences between tax matters and tariff matters. The first difference is that the magnitude of revenues involved is much larger and, even given bilateral agreements on the total taxes owed for a particular activity, the division of revenues between the host and residence country is not a matter of indifference, as it will be for the taxpayer. Thus, there must be rules governing this division, and administrative considerations might dictate that these rules be effected via apparently discriminatory tax practices.

The second difference is that, especially with respect to multinational enterprises, there is tremendous flexibility in where taxable income is reported. Thus, in order to defend their revenues, countries may have to resort to enforcement techniques that are apparently discriminatory.

Finally, a related concern is the presence of many countries that construct their tax systems precisely to attract tax liability away from other countries, with or without the desire to attract real resources. This practice, which we labeled "predatory tax protectionism," complicates the tax enforcement process of nonhaven countries, and emphasizes that the commitment to single (as opposed to zero) taxation is not a multilaterally shared commitment. Apparently discriminatory tax features that serve to uphold single taxation in some cases may be necessary to support free trade taxation.

There is, though, a protectionist temptation that arises in the context of income taxation that does not arise in the context of tariffswhat we called ownership protectionism. The instruments of income tax policy do give governments the capability to differentiate in favor of domestically-owned, or domestically-headquartered, corporations at the expense of foreign corporations, in a way that tariffs do not permit. 
Fundamentally, the principal limitation of the current set of bilateral tax treaties stems directly from their bilateral nature, which in turn follows from the principle of reciprocity. Tax treaties are intended to shift revenues from source to residence jurisdictions by reducing source-based taxation. This shift is generally acceptable, however, only if the reduction in source-based taxation is reciprocal and capital flows in each direction are broadly similar. In that situation, which is typical between developed countries, it makes sense to mutually reduce source-based taxes because each country will collect more residence-based taxes (assuming it gives a credit for sourcebased taxation). This explains why there are relatively fewer treaties between developed and developing countries (capital flows are too lopsided). It also explains why tax treaties are bilateral and do not contain a most-favored-nation provision (that is, cannot be automatically extended to third countries). This limitation means that the tax treaty network cannot deal adequately with the distortions (predatory tax protectionism) caused by either production or traditional tax havens. Traditional tax havens are not party to tax treaties because they typically do not impose an income tax. Production tax havens (as well as similar regimes designed to attract headquarters facilities, known as headquarters tax havens) are located in countries that do impose generally applicable income taxes and grant specific exemptions to the activities they wish to attract. In this case the bilateral treaty network is inadequate because no two countries can agree on abolishing such regimes for fear that multinationals would relocate to third countries that are not covered by the agreement. ${ }^{54}$

\section{Tax and the Current WTO Agreements}

Section II summarized the current WTO agreements as they relate to taxation issues. This Section discusses how these agreements apply to potentially distortive elements in countries' tax rules.

How do the GATT rules apply to the three types of tax havens (production tax havens, traditional tax havens, and headquarters tax havens)? The clearest application is in the case of production tax havens. These regimes are invariably "ring fenced" because they are set up by countries with a real domestic tax base and they do not wish to see that base eroded by the tax concessions granted within the preferential regimes. The EU and OECD reports on harmful tax competition cite dozens of such regimes, even though they limit themselves

\footnotetext{
54 For further elaboration of this point, see Reuven S. Avi-Yonah, Globalization, Tax Competition, and the Fiscal Crisis of the Welfare State, 113 Harv. L. Rev. 1573, 1577 (2000).
} 
only to regimes of member countries and (in the case of the OECD) exclude "real" investments (that is, manufacturing). .55

There seems to be little doubt that such production tax havens constitute prohibited export subsidies under GATT. They invariably involve forgone revenue (that is, they are tax expenditures), are specific to certain taxpayers (in fact they are frequently negotiated deals), and are "in fact" contingent on export performance because the products they involve cannot be targeted at the domestic market.

The case of traditional tax havens is harder. Since there is no income tax, they do not involve "forgone revenue" or a tax expenditure in the traditional sense. Traditional tax havens, however, frequently grant exemptions to the offshore sector from those taxes that they do collect (for example, VAT). Moreover, they frequently involve not just pure investments (which presumably are not covered by the current GATT) but in particular the provision of financial services, such as brokerage or insurance, targeted entirely at foreigners (and frequently ring fenced as well). Services, however, are not covered by the current Subsidies Code. ${ }^{56}$ Thus, traditional tax havens, including that part of their activities that is more than pure passive investment, do not fall within the prohibition on export subsidies unless they can be considered as trading in intangible goods. This is a significant limitation on the scope of the current GATT.

Headquarters tax havens also pose significant analytic problems. This category covers specific regimes (such as the Dutch and Belgian coordination center regimes) designed to attract foreign MNEs, which are akin to production tax havens. Those are presumably export subsidies if they provide goods but not if they only provide services, for the reasons stated above. They also cover things like the U.S. deferral regime $^{57}$ and the European exemption for foreign source income of domestic MNEs. ${ }^{58}$ Are these export subsidies under GATT? If the only activity involved is pure investment (for example, the acquisition of a foreign target), the regime is not covered. But usually there is also the transfer of intangibles, and frequently also the sale of goods to the foreign subsidiaries. In these cases there is trade in goods, and the provision could be an export subsidy.

55 Code of Conduct (Bus. Tax'n)/Primarolo Group, Report to ECOFIN Council, Nov. 29, 1999, reprinted in 2000 Worldwide Tax Daily 49-25 (Mar. 15, 2000); OECD, Progress in Identifying and Eliminating Harmful Tax Practices, Towards Global Co-Operation, Report to the Committee on Fiscal Affairs, June 26, 2000, reprinted in 2000 Worldwide Tax Daily 124-11 (June 27, 2000) [hereinafter Primarolo Report].

56 Subsidies Code, note 6, art. 201.

57 IRC §§ 951-964.

58 Primarolo Report, note 55, at $\S 48$. 
The ultimate question in this regard is whether a deferral or exemption system is itself a tax expenditure, because forgone revenue is a precondition to finding a subsidy under GATT. In a worldwide regime such as that of the United States, the answer is clearly yes (and deferral is in the tax expenditure budget ${ }^{59}$ ). If the transfer of goods to subsidiaries benefiting from deferral, however, is accompanied by adequate transfer pricing enforcement (for example, through royalties), then there is no subsidy (except a subsidy for investment, which is not covered).

What about an exemption regime? The Europeans have argued that the exemption of foreign source income in Europe is part of the normative baseline. ${ }^{60}$ But defining the baseline for the European regimes is hard, since they contain many worldwide features (such as CFC regimes). Thus, we think that it is possible to argue that there is "forgone revenue" here as well, even if it is not reflected in the tax expenditure budget.

But what about the footnote ${ }^{61}$ that specifically excludes regimes designed to avoid double taxation? While the intent of this footnote was to exclude the European regimes, it is not clear whether an exemption regime that does not take into account whether the income was subject to tax at source qualifies as a "measure to avoid double taxation." Fundamentally, a general exemption regime distinguishes between domestic and foreign source activities in a way that frequently subsidizes exports, not just investments, and therefore can be construed as an export subsidy if the income is not taxed at source.

Even if one is satisfied that many of the practices identified by the OECD as "harmful tax competition" and labeled by us "predatory tax protectionism" are covered by existing WTO rules, it does not necessarily follow that WTO adjudication is the best way to address the problem. The recent WTO decision ${ }^{62}$ on the U.S. Foreign Sales Corporation (FSC) is a case in point. Even though the FSC is a welldocumented export subsidy, ${ }^{63}$ it took a major effort to have it adjudicated to be one by the WTO. And although the United States did comply with the decision by repealing the FSC regime, it promptly replaced it with a territorial regime for exports that provides a practi-

59 Budget of the United States Government: Analytical Perspectives, Fiscal Year 2000, at 114 .

60 Gary C. Hufbauer, U.S. Taxation of International Income: Blueprint for Reform 5760 (1992).

61 Subsidies Code, note 6, n.59.

62 GATT Dispute Panel Report on United States-Tax Treatment for "Foreign Sales Corporations" (Oct. 8, 1999), available at http://docsonline.wto.org/GEN_viewerwindow. asp?D://DDFDOCUMENTS/T/WT/DS/108R.DOC.htm.

${ }^{63}$ Mihir A. Desai \& James R. Hines, Jr., The Uneasy Marriage of Export Incentives and the Income Tax, in 15 Tax Policy and the Economy 41 (James M. Poterba ed., 2001). 
cally identical subsidy. ${ }^{64}$ Presumably, this was done in order to bolster the argument that the U.S. provision is no different from European exemption regimes. In any case, the litigation had to begin again (with the outcome again favoring the EU). ${ }^{65}$ The prospect of litigating every one of the 66 regimes identified by the EU and OECD as harmful tax competition under WTO rules is unappetizing, as Robert Green has argued. ${ }^{66}$ On the other hand, the mere possibility of such challenges may provide some needed teeth to the OECD effort.

\section{A Multilateral Agreement on Goods, Services AND INVESTMENT?}

The foregoing discussion has indicated that both the trade and tax regimes can impact the extent to which the goals of free trade are achieved. The tax treaties prevent double taxation as well as most forms of discrimination against foreigners covered by the treaties. Because of their bilateral nature, however, the tax treaties do not do a good job of addressing predatory tax protectionism as embodied in production, traditional, and headquarters tax havens. The trade agreements do a better job in this regard because of their multilateral nature, but are limited in this context to trade in goods, and do not cover trade in services or investment activities. Therefore, the trade agreements clearly apply only to production tax havens.

What is needed (ideally) is a multilateral treaty similar to GATT that will address tax as well as trade issues and that will apply to subsidies for services as well as goods. For example, one of the authors has argued elsewhere that the costs due to tax havens and income shifting may be addressed via a multilateral agreement that would restrict statutory corporate tax rates to lie within a small band and impose sanctions on those countries that choose not to comply. ${ }^{67}$ Countries would be permitted to be magnets for real investment, but would have to do so by offering investment tax credits rather than low statutory tax rates. This (in particular, a minimum statutory corporate tax rate) was

\footnotetext{
64 FSC Repeal and Extraterritorial Income Exclusion Act of 2000, Pub. L. No. 106-519, 114 Stat. 2423.

65 GATT Dispute Panel Report on United States-Tax Treatment for "Foreign Sales Corporations": Recourse to Article 21.5 of the DSU by the European Communities (Aug. 20, 2001), available at http://docsonline.wto.org/GEN_viewerwindow.asp?D:/DDFDOCUMENTS/T/WT/DS/108RW-00.DOC.htm.

${ }^{66}$ Robert A. Green, Antilegalistic Approaches to Resolving Disputes Between Governments: A Comparison of the International Tax and Trade Regimes, 23 Yale J. Int'l L. 79, 129-37 (1998).

67 Joel Slemrod, Tax Principles in an International Economy, in World Tax Reform: Case Studies of Developed and Developing Countries 11 (Michael J. Boskin \& Charles E. McLure, Jr. eds., 1990).
} 
the approach suggested as a first step toward more corporate tax harmonization by the Ruding Committee, ${ }^{68}$ the experts' committee of the European Commission charged with recommending what, if any, tax harmonization should be adopted in concert with the 1992 curtailment of barriers to free trade in goods and services. This suggestion, however, was not embraced by the European Community, and it seems unlikely that it will be embraced by any multilateral body, existing or newly formed, in the foreseeable future.

The current OECD effort to combat harmful tax competition is more limited. ${ }^{69}$ It requires a low or zero tax rate as a condition for defining a tax regime as harmful, but does not envisage a minimum tax rate. ${ }^{70}$ The OECD project applies only to geographically mobile activities (such as financial services) and not to real investment. ${ }^{71}$ In addition, the OECD effort is limited to production and headquarters tax havens in member countries, which leaves out most of the world. ${ }^{72}$ Efforts by the OECD to combat traditional tax havens have met considerable opposition and may not lead to significant limits on such tax havens. A broader OECD effort to craft a multilateral agreement on investment collapsed in the face of internal disagreement and outside criticism. ${ }^{73}$

Since we do not have-and are not likely to have soon-a broad multilateral agreement, (how) should trade agreements distinguish between apparently discriminatory tax practices that are not protectionist, and those that are? In what follows we offer some general rules to serve as the basis for discussion.

Trade agreements should:

1. Accept bilateral tax agreements designed to generate, and allocate between the taxing jurisdictions, a single layer of taxation.

2. Not accept situations in which the direct tax system is merely the vehicle for otherwise proscribed actions, such as tariffs or export subsidies. As we argued above, much of what we labeled "predatory tax protectionism," in fact, can be classified as export subsidies, and other kinds can be labeled as such with a relatively small expansion of the Subsidies Code (that is, applying it to services as well as to trade in goods).

6s Commission of European Communities, Report of the Committee of Independent Experts on Company Taxation 203-04 (1992), available at LEXIS, IBFD Tax Treaties and News File.

69 OECD, Committee on Fiscal Affairs, Harmful Tax Competition: An Emerging Global Issue (1998), available at http://www.oecd.org/pdf/M00004000/M00004517.pdf.

70 Id. at 26.

71 Id.

72 Id. at 3.

73 See David L. Cleeton, European Commission Releases Estimates of Economic Benefits From Potential WTO Agreements, 20 Tax Notes Int'1 261, 264 (Jan. 17, 2000). 
3. Accept statutorily uniform source-based factor taxes, even if the effective tax on factors, by sector, is relatively higher for import-intensive sectors.

4. Accept anti-evasion provisions that deal with predatory tax protectionism, even if they violate nondiscrimination, as long as these provisions do not effectively levy more than a single layer of taxation.

Adherence to these principles would bar substantial interference of trade instruments into tax matters. We favor this result not because we believe that the current system of international taxation causes no significant inefficiencies. On the contrary, we believe that there are significant inefficiencies, caused by a wide divergence in effective source-based factor taxes that vary by country of residence, and widespread tax avoidance and evasion that is abetted by tax haven operations. We believe, however, that except in the case of export subsidies, these problems are not directly related to the standard issues addressed by trade agreements-government policies designed to encourage domestic production of particular goods and services at the expense of imports-and therefore are not well treated by extending in a mechanical way the concepts developed for trade issues (such as most-favored-nation status) to cover tax issues. A multilateral instrument devoted specifically to taxes is a more appropriate way to handle these issues. Whether, in the future, the WTO might be the institutional vehicle for negotiating such a tax instrument is a tactical question we leave open for now. 